\title{
ORIENTASI SEKSUAL KOMUNITAS GAY MUSLIM DI DAERAH ISTIMEWA YOGYAKARTA
}

Harpan Reski Mulia ${ }^{1}$

${ }^{1}$ Universitas Islam Negeri Sunan Kalijaga, Yogyakarta

* CORRESPONDENCE: $\square$ harpanreskimulia@gmail.com

\begin{abstract}
This article aims to explore gay sexual orientation which is clashed with Islam and Psychology. In Islamic teachings, gay behavior that refers to acts of liwat is an act that is forbidden. Even the death penalty is a threat to people who have a sexual orientation to the same sex. Based on this matter, this paper explores the case, where religious translations appear to meet irreconcilable needs, namely between gay and Islam. The research method used in this paper is qualitative with an approach Interpretative Phenomenological Analysis (IPA). The formal object used is the lens of the Vaillant version of the selfdefense mechanisms theory. The results found in this study show that gays admit that their sexual orientation is a sin. They are aware of this as a whole, but none of the subjects of this study wish to leave Islam. The methods of gay in reconciling the conflict are: First, Islam is seen as a forgiving religion: Secondly, it is sinful to have sex outside marriage either homo or hetero and Third, sexual orientation is considered as the nature of God.
\end{abstract}

\begin{abstract}
Abstrak
Artikel ini bertujuan untuk mengeksplore orientasi seksual kaum gay yang dibenturkan dengan Agama Islam dan Psikologi. Di dalam Ajaran Islam, perilaku gay yang merujuk pada perbuatan liwath merupakan perbuatan yang diharamkan. Bahkan hukuman mati menjadi ancaman bagi orang yang memiliki orientasi seksual kepada sesama jenis. Berdasarkan hal tersebut tulisan ini mengeksplorasi kasus, dimana terjemah agama muncul untuk memenuhi kebutuhan yang tidak bisa didamaikan, yaitu antara gay dan Islam. Metode penelitian yang digunakan dalam tulisan ini adalah kualitatif dengan pendekatan Interpretatif Phenomenological Analisis (IPA). Objek formal yang digunakan adalah lensa teori mekanisme pertahan diri versi Vailant. Adapun hasil yang ditemukan dalam penelitian ini menunjukkan bahwa, gay mengakui bahwa orientasi seksual yang mereka miliki adalah dosa. Mereka menyadari hal tersebut secara utuh, namun tidak ada satupun dari subjek penelitian ini berkeinginan untuk meninggalkan Islam. Adapun cara-cara yang dilakukan gay dalam mendamaikan konflik tersebut, adalah: Pertama, Islam dipandang sebagai agama pengampun: Kedua, berdosa jika melakukan seks diluar nikah baik homo maupun hetero; dan Ketiga, orientasi seksual dianggap sebagai fitrah dari Tuhan.
\end{abstract}

\section{A. Pendahuluan}

Kompleksitas permasalahan seks dan gender tidak pernah sunyi dari ruang-ruang diskusi. Keharusan untuk menyesuaikan identitas gender dan identitas seks, menjadi tolak ukur untuk menilai seseorang normal dan abnormal, hal ini dipicu karena norma-norma yang dianut suatu kelompok masyarakat, terutama berkenaan dengan norma agama. Seperti di Indonesia dengan penduduk mayoritas Islam, wacana tentang moralitas seksual telah membentuk mindset masyarakat 
dengan stigma zina, yakni tindakan pemerkosaan, incest, perselingkuhan di luar nikah, pelacuran, seks pranikah dan pemerkosaan menurut hukum, dan hubungan homoseksual ${ }^{1}$.

Meskipun Indonesia bukan negara Islam, namun secara populasi Islam merupakan agama mayoritas masyarakat. Sesuai dengan data terakhir tahun 2010 yang dikeluarkan oleh Badan Statistik Negara Indonesia bahwa dari 237.641.326 total penduduk, 207.176.162 atau 87.18\% penduduk memeluk agama Islam, di Yogyakarta sendiri dari 3.457.491 total penduduk, 2.179.129 atau $91.949 \%$ penduduk memeluk agama Islam $^{2}$.

Sementara itu, negara dengan populasi mayoritas Islam ini, terdapat kelompok masyarakat yang mendefinisikan dirinya sebagai gay yang ingin diakui keberadaannya, hal ini dibuktikan dengan hadirnya beberapa aplikasi yang diperuntukkan bagi gay seperti Jack'd, Grindr, Hornet, Blued. Aplikasi ini menjadi media untuk penegasan identitas dan negosiasi ruang bagi keberadaan mereka di ruang publik, karena aplikasi ini juga bisa diakses semua orang, maka aplikasi ini membuka kesempatan untuk saling berinteraksi, beradu argumentasi bagi khalayak umum ${ }^{3}$.

Gay didefinisikan laki-laki yang menginginkan hubungan seksual kepada sejenis. Berbeda dengan waria, karena waria di Indonesia mendefinisikan dirinya sebagai seorang yang memiliki jiwa (soul) perempuan namun berada dalam tubuh pria ${ }^{4}$, dengan demikian, gay di sini didefinisikan sebagai seorang laki-laki dan berpenampilan layaknya seorang laki-laki, namun memiliki hasrat seksual terhadap laki-laki (sejenis). Maka agama memandang bahwa hasrat seksual laki-laki kepada sejenis tersebut tidak diperkenankan, khususnya Islam secara normatif memandang perilaku tersebut dilarang dan merupakan perbuatan haram dan suatu bentuk kejahatan dan pelakunya dijatuhi maksimal hukuman mati ${ }^{5}$.

Banyak peneliti yang telah mengkaji kecenderungan seseorang melakukan hubungan homoseksual. Di antara para peneliti tersebut menyimpulkan adanya keterkaitan Kromosom X terhadap perilaku homoseksual pada laki-laki dan perempuan. Namun, tidak ada kesepakatan di antara mereka bahwa perilaku homoseksual disebabkan faktor genetik (turunan yang diwariskan). Bahkan, Misri Gozan ${ }^{6}$, melalui studi pustaka dengan menilik perilaku homoseksual mencari akar pada faktor genetik memberikan kesimpulan bahwa, tidak ada data yang kuat tentang munculnya perilaku homoseksual disebabkan faktor genetik. ${ }^{78910}$

${ }^{1}$ Linda Rae Bennett, "Zina and the Enigma of Sex Education for Indonesian Muslim Youth," Sex Education 7, no. 4 (November 1, 2007): 371-86, https://doi.org/10.1080/14681810701635970.

2 "Sensus Penduduk 2010 - Penduduk Menurut Wilayah dan Agama yang Dianut | Indonesia,” BPS, accessed October 1, 2018, https://sp2010.bps.go.id/index.php/site/tabel?tid=321.

3 Puji Rahayu, Rina Satriani, and Hamada Adzani Mahaswara, "Aplikasi Gay: Perjuangan Dan Ruang Negosiasi Identitas Bagi Kaum Gay Muda Di Yogyakarta,” Jurnal Studi Pemuda 3, no. 2 (June 23, 2016): 99-109.

${ }^{4}$ Tom Boellstorff, The Gay Archipelago: Sexuality and Nation in Indonesia (Princeton: Princeton University Press, 2005).

${ }^{5}$ Pernyataan ini dikutip dari Fatwa Majelis Ulama Indonesia (MUI) tertanggal 31 Desember 2014 "LesbianGay-Sodomi-Dan-Pencabulan.Pdf," accessed October 2, 2018, https://mui.or.id/wp-content/uploads/2017/02/LesbianGay-Sodomi-dan-Pencabulan.pdf.

6 Misri Gozan, "Perilaku Homoseksual: Mencari Akar Pada Faktor Genetik," Nizham Journal of Islamic Studies 4, no. 1 (October 12, 2017): 75-87.

7 D. Hamer et al., "A Linkage between DNA Markers on the X Chromosome and Male Sexual Orientation," Science 261, no. 5119 (July 16, 1993): 321-27, https://doi.org/10.1126/science.8332896.

${ }^{8}$ George Rice et al., "Male Homosexuality: Absence of Linkage to Microsatellite Markers at Xq28," Science 284, no. 5414 (April 23, 1999): 665-67, https://doi.org/10.1126/science.284.5414.665.

9 Andrea Camperio Ciani, Francesca Iemmola, and Stan R. Blecher, "Genetic Factors Increase Fecundity in Female Maternal Relatives of Bisexual Men as in Homosexuals," The Journal of Sexual Medicine 6, no. 2 (February 2009): 449-55, https://doi.org/10.1111/j.1743-6109.2008.00944.x. 
Adapun dari sudut pandang sosiologi, para akademisi juga telah banyak meneliti dengan tujuan mengidentifikasikan proses penemuan orientasi seksual pada gay dan lesbian, seperti Alvesdan Albuquerque $^{11}$, mendesain penelitian cross-sectional dan studi kualitatif dengan wawancara semi struktur terhadap 27 gay dan lesbian di Juazeiro, Ceará, Brazil. Kesimpulan yang didapatkan Alves dan Albuquerque, pada masa kanak-kanak mempunyai manifestasi pertama dari hasrat seksual dan tertarik kepada orang yang mempunyai jenis kelamin yang sama, kemudian hasrat seksual ini juga muncul setelah dewasa karena telah melakukan hubungan seks dengan sesama jenis untuk pertama kali. Di samping itu Prabowo dan Asriwandari ${ }^{12}$ menyimpulkan dalam penelitiannya bahwa proses internalisasi nilai dan sosialisasi menjadi salah satu penyebabnya, dengan pengertian bahwa perilaku penyimpangan seks bukan bawaan dari lahir, namun terjadi karena proses pembelajaran sehingga membentuk suatu kebiasaan. Selain itu, Studi antropologi tentang gay di Indonesia seperti buku Tomm Boellstorff, "The Gay Archipelago" dengan menggunakan lensa teori sulih suara budaya (dubbing culture) menjelaskan bahwa gay bukanlah serapan dari negara "barat" akan tetapi ia merupakan produk budaya Indonesia sendiri, dimulai dari warok atau bissu. Melalui pendekatan ethno-locality, Boellstorff juga telah mengungkap gagasan yang tidak kalah penting yaitu, gay yang ada di Indonesia menganggap dirinya sebagai bagian dari negara Indonesia (Gay Indonesia), tanpa mengidentifikasikan dirinya sebagai etno-lokal(gay Bali, Gay Makassar dan lain sebagainya), seperti halnya masyarakat hetero-seksual di Indonesia yang cenderung menyandarkan diri kepada etnis-etnis lokal yang ada di Indonesia, seperti orang Jawa, orang Sumatera, orang Makassar dan etnis lokal lainnya ${ }^{13}$.

Bukan hanya secara nasional gay di "diskriminasi", gay juga mendapat tekanan dari beberapa pihak keluarga terutama dari saudara laki-laki dan ayahnya, ${ }^{14}$ sehingga setiap gay berbeda-beda pada tahap pembentukan identitas diri (self-identity), tergantung seberapa nyaman gay pada orientasi seksualnya, demikian penemuan Mastuti, dkk, yang melihat dari tiga respondennya, pertama mencapai pada tahap sintesis, kedua sampai pada tahap penerimaan (tolerance) dan ketiga sampai pada tahap kebanggaan (pride) ${ }^{15}$.Menurut Cass ${ }^{16}$ seorang gay, mempunyai fase-fase dalam menentukan identitas gendernya, dalam sebuah penelitian Cass menunjukkan bahwa, ada enam fase yang dilalui oleh gay (homoseksual pada umumnya) untuk mencapai identitas gender, yakni, identity confusion, identity comparison, identity tolerance, identity acceptance, identity pride, identity synthesis.

${ }^{10}$ Francesca Iemmola and Andrea Camperio Ciani, "New Evidence of Genetic Factors Influencing Sexual Orientation in Men: Female Fecundity Increase in the Maternal Line," Archives of Sexual Behavior 38, no. 3 (June 1, 2009): 393-99, https://doi.org/10.1007/s10508-008-9381-6.

11 Maria Juscinaide Henrique Alves, Jeanderson Soares Parente, and Grayce Alencar Albuquerque, "Homosexual Orientation in Childhood and Adolescence: Experiences of Concealment and Prejudice," Reprodução \& Climatério 31, no. 2 (May 2016): 68-75, https://doi.org/10.1016/j.recli.2016.03.002.

12 Dwi Ananto Prabowo and Hesti Asriwandari, "Latar Belakang Sosiologis Dalam Terbentuknya Pola Perilaku Homoseksual Gay (Studi Kasus Di Kota Pekanbaru),” Jurnal Online Mahasiswa (JOM) Bidang Ilmu Sosial Dan Ilmu Politik 3, no. 2 (June 9, 2016): 1-13.

${ }^{13}$ Tom Boellstorff, The gay archipelago: sexuality and nation in Indonesia (Princeton: Princeton University Press, 2005).

${ }^{14}$ David Bobrow and J. Michael Bailey, "Is Male Homosexuality Maintained via Kin Selection?," Evolution and Human Behavior 22, no. 5 (September 1, 2001): 361-68, https://doi.org/10.1016/S1090-5138(01)00074-5.

${ }^{15}$ Ratri Endah Mastuti, Rachmad Djati Winarno, and Lita Widyo Hastuti, "Pembentukan Identitas Orientasi Seksual Pada Remaja Gay," PREDIKSI 1, no. 2 (2012): 194.

${ }^{16}$ Vivienne C. Cass, "Homosexuality Identity Formation:," Journal of Homosexuality 4, no. 3 (April 24, 1979): 219-35, https://doi.org/10.1300/J082v04n03_01. 
Kemudian, penelitian terdahulu yang sangat memberikan kontribusi dalam artikel ini, adalah ketika gay dikaji dengan kacamata agama, seperti tulisan Badaruddin ${ }^{17}$ yang bertujuan untuk melihat bagaimana hukum Islam memandang LGBT, dalam tulisan tersebut ia memberikan kesimpulan bahwa praktik LGBT hukumnya haram, karana merusak kemuliaan dan martabat manusia dan dapat menimbulkan penyakit kelamin. Berbeda dengan Masthuriah ${ }^{18}$, dengan menggunakan pendekatan sosial humanities kontemporer, tujuan utama dari kajiannya adalah agar agama Islam yang menjadi simbol dan label MUI, tidak terkesan Islam yang keras, radikal dan bertentangan dengan HAM. Ia memberikan kesimpulan bahwa perbedaan adalah suatu keniscayaan baik perbedaan hak-hak orang lain, perbedaan orientasi seksual, perbedaan gender dan semua macam perbedaan, yang tujuan utamanya adalah untuk saling mengenal secara universal dan holistik bukan parsial, agar sebuah ikatan persahabatan dan persaudaraan. Selain itu penelitian Koeswinano dan Mustahuddin ${ }^{19}$ juga dilakukan terhadap gay di Yogyakarta, subjek dari penelitian ini adalah transvestites (waria) untuk mengungkap proses marjinalisasi, menjalankan agama, dan cara gay (waria) dalam memandang diri mereka sebagai bagian dari masyarakat Muslim. Penelitian ini dinilai berbeda dengan tulisan ini dari dua aspek. Pertama subjek yang dijadikan adalah waria, sementara subjek yang dijadikan dari penelitian ini adalah gay, sedangkan sebagaimana dikemukakan diatas gay dan waria berbeda. Kedua, penelitian ini secara spesifik bertujuan untuk mengetahui cara harmonisasi yang dilakukan oleh gay dengan Islam, sementara Koeswinano dan Mustahuddin adalah gay (waria) dengan masyarakat Muslim.

Beranjak dari beberapa tulisan di atas, tampak bahwa pisau analisis yang digunakan adalah agama, dengan pengertian agama menjadi subjek dan gay sebagai objek. Berbeda dengan tulisan ini, maka penelitian ini memaparkan gay dijadikan subjek dan agama dijadikan objek. Meskipun demikian, ada penelitian yang telah mengaji pemahaman gay terhadap agama, seperti penelitian Parlindungan dan Brilianty ${ }^{20}$ terhadap dua orang gay, dengan tujuan untuk mengetahui gambaran sikap religiositas para gay, namun penelitian ini hanya memaparkan sikap-sikap gay tersebut.

Dari penjelasan di atas, maka tulisan ini mengeksplorasi kasus, di mana terjemahan agama muncul untuk memenuhi kebutuhan yang tidak bisa didamaikan, yaitu antara gay dan Islam. Islam sebagai agama yang dipilih, bukan memberikan pemahaman bahwa agama lain lebih toleran dalam hal ini, sebagaimana dalam penganut Kristen juga beranggapan bahwa gay termasuk dalam immoral seksualitas, sehingga para pemuda Kristen yang terlibat dalam Immoralitas tersebut memberikan tiga alternatif yaitu, Pertama, casting off religion altogether. Kedua, reinterpreting religious morality. Ketiga, practicing a double morality ${ }^{21}$.

Sebagai kerangka teoretis yang digunakan untuk menganalisis data dalam penelitian ini adalah self-defense mechanism (mekanisme pertahanan diri). Sebagaimana tujuan penelitian ini, yaitu

${ }^{17}$ Dharma Setyawan, ed., Proceding: Tinjauan Terhadap Lebian Gay Biseksual dan Transgender (LGBT) Dari Perspektif Hukum Pendidikan Dan Psikologi (Lampung: Program Pascasarjana STAIN Jurai Siwo Metro Lampung, 2016), 117-32.

${ }_{18}^{18}$ Dharma Setyawan, 16-25.

${ }^{19}$ Koeswinarno Koeswinarno and Mutolehudin Mustolehudin, "Islam, Gay, and Marginalization: A Study on the Religious Behaviours of Gays in Yogyakarta," Indonesian Journal of Islam and Muslim Societies 7, no. 1 (June 1, 2017): 125-52, https://doi.org/10.18326/ijims.v7i1.125-152.

${ }^{20}$ Raja Parlindungan and Amalia Roza Brilianty, "Gambaran Religiusitas Pada Gay," Jurnal RAP 5, no. 1 (February 24, 2017): 92-102.

${ }^{21}$ Teguh Wijaya Mulya, "From Divine Instruction to Human Invention: The Constitution of Indonesian Christian Young People's Sexual Subjectivities through the Dominant Discourse of Sexual Morality," Asian Studies Review 42, no. 1 (January 2, 2018): 53-68, https://doi.org/10.1080/10357823.2017.1407918. 
untuk mengeksplorasi cara gay Muslim untuk mengkompromikan antara orientasi seksual mereka dan agama. Keadaan seperti ini maka gay dengan orientasi seksual yang bertentangan dengan Islam, mereka dipahami sebagai orang yang cemas. Maka, penting untuk memahami reaksi mereka terhadap kesulitan-kesulitan yang terkait dengan mekanisme pertahanan mereka. Sebagaimana secara definisi mekanisme pertahanan diri adalah senjata ego ketika seseorang merasa cemas saat keinginan id konflik dengan aturan-aturan $\operatorname{sosial}^{22}$.

Berkenaan dengan teori mekanisme pertahanan diri ini, Vaillant ${ }^{23}$ telah mengategorikan mekanisme pertahan diri kepada empat tingkat yaitu, psychotic, immature, neurotic, dan mature. Tingkatan pertama mekanisme psikotik, yaitu pertahanan diri dari proyeksi delusi, penolakan psikotik, dan distorsi. Tingkatan kedua yaitu mekanisme immature, yaitu melibatkan fantasi, hipokondriasis, perilaku pasif-agresif. Tingkat ketiga mekanisme neurotik, yaitu terdiri dari intelektualisasi, represi, pembentukan reaksi, pemindahan (displacement), disosiasi. Tingkatan keempat adalah mekanisme matur, termasuk pada level ini, sublimasi, altruisme, penekanan, antisipasi, humor. Tulisan ini menggunakan konsep self-defense versi Vailant untuk memeriksa gay menghadapi konflik antara objek seksual dengan kepercayaan terhadap Islam sehingga menciptakan negosiasi diantaranya. Di samping itu, penelitian ini juga akan menentukan jenis mekanisme pertahan diri yang mereka gunakan untuk tetap bertahan pada agama Islam dan menjalankan ibadah sebagaimana biasanya.

Berkenaan dengan pemilihan agama Islam dalam penelitian ini, karena fokus research ini berada di Yogyakarta yang mayoritas Islam, dan di Yogyakarta sendiri dijumpai pesantren seninkamis, sebagai tempat yang memberikan mereka fasilitas untuk beribadah dan mendekatkan diri kepada Allah ${ }^{24}$. Selain itu, Yogyakarta dengan penduduk mayoritas Islam ini, menurut Capriati dan Permana merupakan kota dengan pergerakan gay yang progresif dan aktivis-aktivis yang ada dalam pergerakan tersebut berada dalam ranah religius ${ }^{25}$.

\section{B. Metode Penelitian}

Artikel ini menggunakan metode penelitian kualitatif dengan pendekatan interpretatif phenomenological Analysis (IPA). Penggunaan metode ini dinilai relevan dengan tujuan penelitian, yaitu untuk memahami cara negosiasi antara keinginan objek seksual kepada sejenis (homoseksual) dalam hal ini adalah gay dan pemahaman agama Islam yang secara ideologi menentang keinginan tersebut.

Di samping itu pendekatan fenomenologi ini dirasa sesuai, sebagaimana penelitian fenomenologi membahas pertanyaan tentang kebiasaan, pengalaman keseharian manusia, pengalaman yang diyakini menjadi penting terkait fenomena sosial atau psikologis dalam menjalani waktu, tipikal seseorang atau grup (seperti menjadi pasien kanker), dan perubahan posisi yang biasa atau masalah kontemporer yang menarik (seperti menjadi orang tua atau mengubah peran gender $)^{26}$.

\footnotetext{
${ }^{22}$ Carole Wade and Carol Tavris, Psikologi: Edisi Kesembilan, trans. Padang Mursalin and Dinastuti, 9th ed., jilid 2 (Jakarta: Erlangga, 2007).

${ }^{23}$ George Eman Vaillant, “Adaptive Mental Mechanisms,” American Psychologist 55, no. 1 (2000): 89-98, https://doi.org/10.1037//0003-066X 55.1.89.

${ }^{24}$ Titin Nur hidayati, "Kehidupan Keagamaan Kaum Santri Waria di Pesantren Waria Al-Fatah Senin-Kamis Notoyudan Yogyakarta," Jurnal Falasifa 1 (2010): 16.

${ }^{25}$ Wigke Capriati and Yogi Setya Permana, "Gerak Progresif Gerakan Gay Kontemporer Di Yogyakarta," Jurnal Ilmu Sosial Dan Ilmu Politik 12, no. 1 (2008): 59-77, https://doi.org/10.22146/jsp.10986.

${ }^{26}$ Sharan B. Merriam, Qualitative Research in Practice: Examples for Discussion and Analysis, 1 st ed, The Jossey-Bass Higher and Adult Education Series (San Francisco: Jossey-Bass, 2002).
} 
Adapun pemilihan subjek dalam penelitian ini menggunakan purposive sampling, sebagaimana dalam teknik ini, kriteria subjek harus relevansi dengan pertanyaan penelitian ${ }^{27}$. Maka, subjek dalam penelitian ini mempunyai kriteria, Pertama, laki-laki yang mendefinisikan dirinya sebagai gay (bukan waria); Kedua, beragama Islam; Ketiga, tinggal di Yogyakarta. Subjek ini didapatkan melalui aplikasi yang diperuntukkan bagi para gay, yaitu Jack'd, Grindr, Hornet, Blued. Melalui beberapa aplikasi tersebut, peneliti mendapatkan 7 orang subjek yang bersedia untuk diwawancarai untuk penelitian dengan catatan identitas mereka disembunyikan, hemat peneliti jumlah subjek tersebut telah cukup karena, data yang ditemukan sudah jenuh dan ditandai dengan jawaban dari subjek berputar pada makna yang sama walaupun dengan redaksi yang berbeda.

Teknik pengumpul data yang digunakan dalam penelitian ini adalah: Pertama, wawancara. Wawancara digunakan dalam peneliti ini, adalah untuk menganalisis secara terperinci dan mendalam bagaimana gay memahami kesenjangan antara orientasi seksual mereka yang dilarang agama. Wawancara yang digunakan adalah wawancara semi-terstruktur, sebagaimana Smith juga menjelaskan bahwa pengumpulan terbaik bagi studi IPA dan cara yang memang digunakan oleh kebanyakan studi IPA adalah wawancara semi-terstruktur ${ }^{28}$.

Kedua, observasi. Sebagaimana pada umumnya dalam penelitian kualitatif, observasi digunakan ketika peneliti langsung turun kelapangan untuk mengamati perilaku dan aktivitas-aktivitas $\operatorname{partisipan}^{29}$. Pada penelitian ini, observasi digunakan pada saat berlangsung wawancara. Maka, peneliti tidak hanya mendengarkan jawaban-jawaban subjek. Akan tetapi, melihat atau mengamati bentuk ekspresi (seperti menangis, tertawa, tersenyum dan lain sebagainya) dari subjek ketika memberi jawaban. Hal ini bertujuan untuk mengungkap dari respons gay dalam memandang kesenjangan tersebut.

Ketiga, dokumentasi. Dokumentasi dalam penelitian ini adalah dokumen privat, berupa chat dengan penelitian atau bentuk lain yang mengartikulasikan agama dan orientasi seksualnya. Sebagaimana Creswell mengungkapkan bahwa, dokumen-dokumen kualitatif dapat berupa dokumen publik (seperti, koran makalah, laporan kantor, dsb) ataupun dokumen privat (seperti, buku harian, diary, surat, email, dsb ${ }^{30}$. Ketiga teknik tersebut digunakan secara simultan untuk menggali secara utuh dan holistik.

Teknik analisis data yang digunakan dalam penelitian ini adalah mengacu pada prosedur analisis Miles dan Huberman ${ }^{31}$, yakni dalam penelitian kualitatif analisis data dimulai sejak pengumpulan data secara interaktif dan berlangsung secara terus menerus sampai tuntas dan data yang diperoleh telah jenuh. Aktivitas yang dilakukan dalam menganalisis data adalah reduksi data (data reduction), penyajian data (data display) dan membuat kesimpulan atau verifikasi (conclusion drawing/verification).

\section{Pembahasan}

Para anggota komunitas gay di Yogyakarta menganggap bahwa orientasi seksual mereka, memang bertentangan dengan ajaran Islam. Namun, tidak berarti meninggalkan Islam secara mutlak

\footnotetext{
${ }^{27}$ Jennifer Mason, Qualitative Researching, 2nd ed (London ; Thousand Oaks, Calif: Sage Publications, 2002).

28 A. Smith Jonathan, Qualitative Psychology: Practical Guide to Research Methods, trans. Muhammad Khozim, II (Bandung: Nusa Media, 2013).

${ }^{29}$ John W Cresweel, Research design: pendekatan metode kualitatif, kuantitatif, dan campuran, trans. Achmad Fawaid and Rianayati Kusmini Pancasari (Yogyakarta: Pustaka Pelajar, 2017).

${ }^{30}$ Cresweel.

${ }^{31}$ Matthew B Miles and A. Michael Huberman, Analisis Penelitian Kualitatif, trans. Tjerjep Rohendi Rohidi (Jakarta: UI-Press, 1992).
} 
(murtad). Berbeda dengan hasil penelitian Mulya $^{32}$ bahwa sebagian pemuda Kristen yang terlibat dalam immoralitas, salah satu alternatif adalah meninggalkan agamanya (casting off religion altogether). Karena dalam Islam, keluar dari agama merupakan perbuatan dosa besar yang tidak diampuni, sehingga gay tetap mempertahankan agama Islam. Hal tersebut diutarakan oleh salah satu informan, sebagaimana berikut ini:

"Mungkin ya mas...mmmmm aku berpikir kalau kita suka sama laki-laki...hmmmm apa ya, pokoknya, yaudah aku mikirnya itu keinginan sendiri dan agama juga pilihan hati, jadi gimanapun kelakuan kita kalau hati itu tetap pengen Islam ya tetap Islamlah, gak mungkinkan karna aku gay trus aku ninggalin Islam udah gay itu dosa tambah lagi murtad apa gak tambah dosa, hehehe... pokoknya Islam itu tetap agamakulah, 33

Subjek Ani ${ }^{34}$ juga memberikan pernyataan yang senada dengan di atas, bahwa semua agama, pasti melarang hubungan seperti ini, terutama Islam. Dari pernyataan subjek ini, memberikan gambaran bahwa zina adalah dosa, sebagaimana stigma zina pada masyarakat Indonesia telah tertanam, yaitu melakukan seks dengan seseorang di luar nikah baik sesama atau hetero ${ }^{35}$. Sehingga dalam hal keluar dari agama Islam (murtad) subjek tidak akan memilih alternatif itu, walaupun mengetahui Islam melarang orientasi seksualnya.

Walau orientasi seks gay dilarang dalam agama Islam, tidak menjadi kendala bagi para gay untuk tetap percaya dan menjalankan ajaran Islam seperti: Shalat, Puasa, Infak dan lain sebagainya. Hal ini tergambar dari semua subjek gay yang diteliti, bahwa mereka solat sebagaimana layaknya laki-laki dan tidak seorang dari subjek bimbang terhadap gender mereka. Berbeda dengan waria yang diteliti Susanki dan Oktavia ${ }^{36}$, bahwa waria jarang melaksanakan Shalat Jumat, karena mereka bingung dalam memutuskan posisi mereka sebagai laki-laki atau perempuan.

Berdasarkan temuan penelitian, yaitu para gay mengetahui bahwa orientasi seks terhadap sejenis adalah suatu bentuk dosa dalam ajaran Islam, sehingga dua hal kontradiktif ini membuat gay terkadang merasa cemas. Peneliti menemukan tiga cara yang digunakan gay dalam menggunakan mekanisme pertahan diri dan menjalani kehidupan sebagai gay Muslim, untuk mengurangi kecemasan tersebut, yaitu: Pertama, para gay memberikan penanaman terhadap dirinya tentang Islam sebagai agama pengampun. Kedua, semua bentuk hubungan seks di luar nikah berdosa baik yang hetero maupun homo. Ketiga, mereka berpendapat bahwa orientasi seksual yang mereka miliki adalah fitrah dari Tuhan. Berikut akan dipaparkan di bawah ini:

\section{Islam Sebagai Agama Pengampun}

Menyadari bahwa homoseksual dilarang dalam ajaran Islam dan mendapat dosa. Penelitian ini menemukan, bahwa gay Muslim tidak hanya berhenti pada pendapat itu saja, tetapi mereka memahami dosa adalah urusan individual. Ketika Islam dikaitkan dengan orientasi seksual mereka, sebagian besar subjek langsung menghubungkan dengan kisah Nabi Luth. Sebagaimana hasil wawancara berikut dengan seorang gay yang berasal dari Kebumen dan sudah menetap di Yogyakarta lebih kurang enam tahun, dengan menyadari bahwa orientasi seksual yang dia miliki

\footnotetext{
${ }^{32}$ Mulya, "From Divine Instruction to Human Invention."

${ }^{33}$ Hasil Wawancara AF (inisial), Gay: Islam dan Orientasi Seksual, Perekaman audio, August 17, 2018.

${ }^{34}$ Hasil Wawancara ANI (inisial), Gay: Islam dan Orientasi Seksual, Perekaman audio, August 20, 2018.

${ }^{35}$ Bennett, "Zina and the Enigma of Sex Education for Indonesian Muslim Youth."

36 Susanki and Dian Anggraini Oktavia, "Kehidupan Waria di Jorong Mandiangin, Kecamatan Kinali, Kabupaten Pasaman Barat," Jurnal Ilmu Sosial Mamangan 2, no. 2 (January 12, 2017): 101-7,
} https://doi.org/10.22202/mamangan.1374. 
adalah suatu bentuk dosa, dan secara spontan menceritakan tentang umat nabi Luth, "Agama urusan masing-masing dan berdosa jelas, tapi aku juga ingat kok, kisah nabi Luth, aku juga ingat itu, tapikan yang namanya berdosa dan tidak berdosa, itukan tergantung diri kita,37.

Subjek SZ ${ }^{38}$, juga beranjak dari kisah Nabi Luth ini, menyadari bahwa orientasi seksual kepada sejenis adalah dosa, namun SZ memberikan penjelasan bahwa Allah dalam Islam Maha pengampun dengan sifat Rahman dan Rahim-Nya. Sebagamana ungkapannya berikut ini,

“ya.. aku tau bagaimana kisah nabi Luth disiksa Allah karena suka sama cowok juga, tapikan kisah itu... ooooo mereka umat Nabi Luth suka sama malaikat, ya iyalah dapat siksa, tapi aku itu, jangankan sama malaikat, sama orang yang normal aja gak bakalan aku godain,,, hehehehe...... jadi yang jelas bro... Tuhan itu maha pengampun Arrahman Arrahim, moga Allah ngampunin dosaku, aku percaya gitu aja sih bro".

Tetap pada makna yang sama, subjek HR ${ }^{39}$ dengan penuh kesadaran dia menyatakan bahwa orientasi seksual terhadap sejenis adalah bentuk dosa, namun dengan mengutip kisah seorang wanita Pekerja Seks Komersial (PSK) yang memberi minum seekor Anjing, subjek ini berharap mendapat ampunan dari Allah.

Narasi di atas memperlihatkan bahwa mereka menyadari sebuah kesenjangan dengan orientasi seksual mereka dengan nilai-nilai agama Islam. Untuk menghadapi kesenjangan tersebut, maka bentuk mekanisme pertahanan mereka adalah memberikan rasionalisasi yakni pendistorsian kognitif terhadap kenyataan dengan tujuan, kenyataan bahwa Islam melarang seks sesama jenis dan mendapat dosa, tidak lagi memberikan kesan yang menakutkan. Di sini kemudian muncul penerjemahan terhadap pemahaman agama, yaitu dengan mengambil kisah-kisah tentang ampunan Tuhan, sehingga memberikan keyakinan pada diri mereka sendiri, bahwa Tuhan Maha Pengampun.

Dalam menggunakan rasionalisasi tersebut, mereka terlebih dahulu memahami tentang titik problem yang membuat mereka cemas, artinya rasionalisasi sebagai mekanisme pertahanan diri juga memerlukan sebuah kecerdasan kognitif, sehingga rasionalisasi bisa berfungsi secara efektif untuk menekan kecemasan-kecemasan tersebut. Di samping itu Knoll, dkk mengungkapkan bahwa rasionalisasi ini dapat dipergunakan ketika seseorang bisa berfikir abstrak yang bertujuan untuk menghindari atau meminimalisir dari perasan-perasaan yang mengganggu. ${ }^{40}$

Dengan demikian, di sini juga memperlihatkan bahwa penggunaan rasionalisasi sebagai mekanisme pertahanan diri bagi para gay, hanya mampu meminimalisir dari perasaan-perasaan bersalah dikarenakan orientasi seksual mereka yang bertentangan dengan agama. Sehingga dari analisis ini dapat diambil kesimpulan bahwa, mereka dengan penuh kesadaran tetap mengakui bahwa orientasi seksual mereka adalah bentuk pertentangan dengan agama dan pernyataan bahwa agama Islam adalah agama pengampun merupakan bentuk rasionalisasi mereka untuk mengurangi dua hal yang berbenturan tersebut.

\section{Berdosa sebagai Bentuk Seks (Hetero/Homo)}

Temuan ini, juga memperlihatkan suatu bentuk kesadaran dari stigma zina dalam Islam, yakni melakukan persetubuhan dengan orang yang belum terikat dalam pernikahan. Yang membedakan

${ }^{37}$ GPY (inisial), Gay: Islam dan Orientasi Seksual, Perekaman audio, August 16, 2018.

${ }^{38}$ SZ (inisial), Gay: Islam dan Orientasi Seksual, Perekaman audio, July 29, 2018.

${ }^{39}$ Hasil Wawancara HR (inisial), Gay: Islam dan Orientasi Seksual, Perekaman audio, August 12, 2018.

40 Megan Knoll, Claire J. Starrs, and J. Christopher Perry, "Rationalization (Defense Mechanism)," in Encyclopedia of Personality and Individual Differences, ed. Virgil Zeigler-Hill and Todd K. Shackelford (Cham: Springer International Publishing, 2016), 1-5, https://doi.org/10.1007/978-3-319-28099-8_1419-1. 
antara hubungan seks sejenis dan berlainan jenis adalah hubungan seks sejenis dalam ajaran Islam secara khusus sampai saat ini tidak ada celah, sementara bagi yang berlainan jenis dapat diterima ketika telah melaksanakan resepsi pernikahan. Dua hal inilah kemudian yang membangun stigma zina di Indonesia ${ }^{41}$.

Demikian juga, mereka mengakui bahwa seks yang mereka lakukan adalah bentuk dosa dalam kategori zina, namun dengan memberikan bentuk proyeksi, yaitu memberikan gambaran bahwa berhubungan seks hetero yang belum menikah juga merupakan bentuk dosa. Sebagaimana proyeksi digunakan untuk memberikan distorsi terhadap tekanan-tekanan psikis dengan mengalihkan kepada eksternal. ${ }^{42}$ Maka di sini, mereka memberikan pengalihan kepada semua orang yang melakukan hubungan seks diluar nikah. Hal ini terekam dalam hasil wawancara dengan SZ ${ }^{43}$, sebagai berikut:

“...dosa, ya jelas dosa bro, aku sadar oooo aku tau bro, tapi ya bro dalam Islam itu, dilarang secara keseluruhan,,, hhhhmmm yang namanya oooooo seks, yaaa artinya belum nikah, jadi kita sama-sama dosa bro, hubungan gini karna tidak menikah trus melakukan seks ya dosa, laki-laki sama cewek juga melakukannya kalau gak nikah tetap dosa juga, buat apa munafik ya kan, semua orang butuh bro, Cuma ya sama siapa itu tergantung bro”.

Senada dengan pendapat subjek SZ, AR ketika peneliti bertanya bahwa dalam ajaran Islam hubungan antara sejenis merupakan tindakan yang tidak diperkenankan, memberikan bentuk proyeksi kepada orang-orang yang melakukan seks diluar nikah merupakan bentuk dosa, sebagaimana tergambar dalam transkrip wawancara dibawah ini:

"ya iya mas, dosa... semua orang Islam, baik normal maupun tidak pasti bilang kalau hubungan sesama itu dosa, tapi ya mas, dosa itu about yourself, tentang diri sendiri. Kalau ngelakuin itu hubungan intim, gak usah gay juga berdosa kok mas, lagian aku berfikir gini mas, hmmmm orang gak usah ikut campur dengan kehidupanku, iya aku berdosa, tapi apa orang itu bersih dari dosa? Gak ada orang yang bersih dari dosa, mending daripada ngurusin hidup kayak aku ini, mending orang tu, ngurusin hidup orang-orang yang melakukan diluar nikah, itu lebih bahaya dari kita, kenap? Ooo karna kita gak bakalan ngelahirin, lah itu ntar,,, aborsi kalau gak mau punya anak, nah itu dosanya lebih besar to, udah ngelakuin bunuh anak lagi, iya kan.",44

Dari uraian di atas, dilihat bahwa mereka mengakui bahwa hubungan di antara sesama lelaki yang mereka jalani adalah bentuk dosa dalam ajaran Islam, namun ketika kesadaran bentuk dosa yang berimplikasi pada tekanan psikis mereka, proyeksi menjadi salah satu bentuk defense yang mereka gunakan untuk mengurangi rasa cemas tersebut, bentuk proyeksi yang mereka gunakan adalah dengan memberikan sebuah pemahaman bahwa dalam ajaran agama Islam semua jenis seks di luar nikah adalah dosa dan mengalihkan kepada semua orang yang melakukan seks di luar nikah. Sejalan dengan pendapat Zaviera ${ }^{45}$ bahwa proyeksi (Projection) Adalah mekanisme dengan apa seseorang melindungi dirinya dari kesadaran akan tabiat-tabiatnya sendiri yang tidak baik, atau perasaan-perasaan dengan menuduhkannya kepada orang lain. Menyalahkan orang lain mengenai

${ }^{41}$ Bennett, "Zina and the Enigma of Sex Education for Indonesian Muslim Youth."

42 Andrew McKinlay and Chris McVittie, Social Psychology and Discourse (Malden, MA; Oxford: WileyBlackwell Pub, 2008), 137.

${ }^{43}$ SZ (inisial), Gay: Islam dan Orientasi Seksual.

${ }^{44}$ Hasil Wawancara AR (inisial), Gay: Islam dan Orientasi Seksual, Perekaman audio, August 5, 2018.

${ }^{45}$ Ferdinand Zaviera, Teori Kepribadian Sigmund Freud, III (Yogyakarta: PRISMASOPHIE, 2016), 73. 
kesulitannya sendiri yang tidak baik. Atau dengan kata lain, proyeksi merupakan usaha untuk menyalahkan orang lain mengenai kegagalannya, kesulitannya atau keinginan yang tidak baik.

\section{Fitrah dari Tuhan}

Dua temuan di atas, memperlihatkan bahwa subjek yang diteliti menggambarkan bahwa hubungan seks di antara sesama laki-laki adalah dosa. Namun di satu sisi, mereka berpendapat bahwa hasrat kepada sejenis ini merupakan ketetapan dari Tuhan, atau yang mereka istilahkan dengan fitrah. Jadi, kata fitrah yang dimaksudkan dalam temuan ini adalah merupakan ketetapan dari Tuhan. Ketika mereka tetap pada pengakuan bahwa orientasi seksual mereka dan Islam memang tidak dapat didamaikan, maka rencana Allah dan ke Maha Kuasaan-Nya menjadi bentuk defense yang mereka gunakan dalam mendamaikan konflik tersebut.

Mengingat bahwa Tuhan Maha Kuasa, Maha Berkehendak dan telah menetapkan segala sesuatunya sebelum manusia dilahirkan, maka mereka memahami bahwa Tuhan telah menciptakan mereka dengan orientasi seksual kepada sesama laki-laki. Namun, temuan ini juga menemukan bahwa mereka tidak menyalahkan Tuhan walaupun telah menetapkan orientasi seksual mereka berbeda pada umumnya, akan tetapi mereka hanya sampai pada kesimpulan bahwa ketetapan dari Tuhan tersebut tidak bisa diganggu gugat karena Tuhan tetap dipahami Maha Kuasa dan Maha Berkehendak.

Jawaban ini juga bukan merupakan jawaban pertama yang mereka gunakan dalam merespons tentang Islam dan orientasi seksual yang mereka miliki, namun mereka memberikan respons tentang ini, ketika mereka telah sampai pada kesimpulan bahwa orientasi seks kepada sejenis dalam Islam memang tidak diperkenan dan tidak ada lagi celah dalam mendamaikannya. Di samping itu jawaban ini juga tidak didapatkan dari semua responden yang digunakan dalam penelitian ini, hal ini menurut peneliti karena, pemahaman mereka tentang konsep sifat Maha Kuasa Tuhan dan background pendidikan mereka, sehingga temuan ini hanya berkutat pada mereka yang pernah menempuh pendidikan pada Pondok Pesantren dan Madrasah Aliyah, sebagaimana GPY, SZ, dan ANI. Sedangkan empat subjek yang digunakan dalam penelitian ini tidak pernah menempuh pada jenjang pendidikan Pondok Pesantren atau Madrasah Aliyah.

"Wes (bahasa jawa artinya "sudah"”) tak bilang, dan aku akui to mas, ini itu dosa, hooh. Tapi yo aku sendiri rak (tidak) ngerti, rak ngerti e opo?. Aku juga gak mau mas jadi gini, aku juga mau hidup normal seperti layaknya laki-laki yang suka emang sama perempuan, tapi opo to mas, semakin aku berfikir dan buat aku stres sama apa yang aku lakuin semua jadi gak nentu to. Yo aku, emang nalahin diri aku sendiri to, tapi yo pie? Iki (ini) ketetap dari Allah to mas, rak iso (tidak bisa) diingkari, dan emang ini itu, ujian dari Tuhan apa aku bisa membendung hasratku atau tidak. Tapi mas, sampai sekarang menurutku ini itu fitrah dari Allah dan aku gak bisa mengubahnya, aku hanya bisa menahannya." $" 46$

Narasi ini memperlihatkan, bagaimana hasrat seksual yang dimilikinya dipahami sebagai rencana dan ketetapan dari Tuhan, fitrah Tuhan menjadi bentuk defense yang digunakan, ketika keinginan tersebut tertekan dalam ajaran Islam. Suatu bentuk defense mechanism dalam menekan keinginan id seperti ini, Vailaint ${ }^{47}$ menyatakan bahwa salah satu manfaat dari defense mechanism ini yaitu untuk mempertahankanrasa cemas, rasa malu, dan rasa bersalah dalam batas-batas yang dapat diterima selama konflik yang muncul diterima dengan kesadaran dan budaya. Senada dengan

${ }^{46}$ ANI (inisial), Gay: Islam dan Orientasi Seksual.

47 George Eman Vaillant, "Ego Mechanisms of Defense and Personality Psychopathology," Journal of Abnormal Psychology Vol. 103, no. No. 1 (1994): 44-50, https://doi.org/0021-843X/94/S3.00. 
narasi diatas subjek SZ juga memberikan respons yang senada yakni bahwa orientasi yang ia miliki merupakan ketetapan dari Tuhan dan fitrah yang telah Allah berikan kepadanya.

"Tadi ya bro, aku menyadari ini dosa ya, kalau melihat agama, ini juga salah. Yang lain Tuhan aku gak suka, tapi nyatanya aku diciptakan dari dulu kayak gini, ya inilah fitrah yang harus aku terima, yang udah ditetapkan Tuhan pada zaman azali, gitu gak sih, mumet sebenarnya. Jadi pusing kalau mikirin ini, ah... sudahlah bro, absurd kalau dipikir-pikirkan. Tapi Ya itu, mau gak mau, terima gak terima kalau yang suka sama cowok itu salah gitu lo. Karna hukum inikan emang Tuhan yang ngatur, jadi ya gimanapun sebenarnya kita gak boleh ingkar sama ketentuan Tuhan ${ }^{, 48}$.

Subjek ANI dibawah ini, dengan menceritakan kisahnya, bahwa sejak kecil sudah merasakan hal yang berbeda dari perasaannya laki-laki pada umumnya menjadi alasan kuat baginya untuk menyatakan bahwa orientasi seksual yang dia miliki merupakan fitrah dari Tuhan, dan tidak bisa menyalahkan diri sendiri dan juga tidak menyalahkan Tuhan yang telah menetapkan orientasi seksualnya.

"pie yo mas?, di satu sisi Islam melarang hubungan kayak gini, di sisi lain secara fitrah Tuhan menciptakan keinginanku kayak gini, karna yo mas, dari kecil aku emang udah suka sama cowok, (peneliti: dari kecil?), iya mas, pokok e aku gak tau mulai kapan, yang jelas mas, sejak kecil aku udah suka sama cowok, jadi kalau cowok itu ada rasa yang beda dari cewek, hmmm opo yo, pokok e gitu wae. Jadi mas ini menurutku fitrah dari Tuhan, aku bisa apa to kalau Tuhanku udah netapkan keinginanku seperti ini. Aku gak nyalahin Tuhan juga to mas, nyalahin diri sendiri juga gak bisa, jadi hmmm apa ya mas, hmmm apa ya, pokok e jalanin waelah mas apa yang udah direncanain Tuhan itu, percaya aja Tuhan itu Maha Mengatur, pasti ada jalan keluarnya suatu saat nanti,"49

Dari ketiga narasi di atas, memberikan pemahaman di satu sisi dengan penuh kesadaran semua subjek dalam penelitian ini mengakui bahwa orientasi seksual yang mereka miliki merupakan dosa dalam ajaran Islam. Namun di sisi lain, orientasi seksual yang mereka miliki juga dipahami sebagai fitrah atau ketetapan dari Allah yang tidak dapat dirubah, dengan pengertian bahwa orientasi seksual yang mereka miliki sudah tertanam dalam jiwa mereka sejak kecil. Sehingga, ketika benturan antara ketetapan Allah dan pemahaman dosa dalam orientasi seksual mereka tersebut, menjadikan mereka pusing dan tertekan di dalam diri mereka.

Kemudian, temuan ini juga memperlihatkan bahwa, orientasi seksual kepada sejenis bukan karena ketidak tahuan akan agama, dalam pengertian bahwa mereka yang mempunyai orientasi seksual kepada sesama juga mengetahui bahwa dalam agama Islam hal itu dilarang atau haram. Di samping itu juga pemahaman agama terkhusus pada Maha Kausa dan Maha Mengatur Tuhan menjadi argumen mereka dalam menyatakan orientasi seksual kepada sejenis ini, dengan demikian konsep pemahaman agama mereka menjadi defense mechanism ketika agama menekan keinginan id mereka.

\section{Kesimpulan dan Saran}

Dari hasil pembahasan di atas, maka temuan penelitian ini dapat disimpulkan bahwa, gay Muslim pada penelitian ini tidak seorangpun yang tidak mengetahui bahwa Islam melarang orientasi seksual yang mereka miliki. Walaupun mereka memiliki orientasi seksual yang bertentangan dalam konsep Islam, tetapi tidak menjadi alasan bagi mereka untuk meninggalkan Islam secara mutlak atau murtad, karena alasan bahwa murtad adalah dosa yang paling besar dalam

\footnotetext{
${ }^{48}$ SZ (inisial), Gay: Islam dan Orientasi Seksual.
}

${ }^{49}$ ANI (inisial), Gay: Islam dan Orientasi Seksual. 
agama Islam. Kemudian gay juga berbeda dengan waria pada keraguan menjalankan beberapa ajaran Islam, jika waria pada menjalankan solat Jumat ragu, karena bingung dalam memutuskan konsep diri mereka apakah laki-laki atau perempuan, maka gay sepenuhnya menyatakan bahwa mereka adalah laki-laki tanpa keraguan.

Adapun cara gay dalam mendamaikan konflik antara orientasi seksual yang mereka miliki dengan ajaran Islam yang melarangnya adalah dengan tiga argumen yaitu: Pertama. Argumen tentang Islam adalah agama yang pengampun; Kedua. Argumen tentang semua bentuk zina, yaitu melakukan hubungan seks diluar nikah baik secara hetero-seksual maupun homo-seksual; Ketiga. Argumen bahwa orientasi seksual yang mereka miliki merupakan fitrah dari Tuhan yang telah ditetapkan oleh Tuhan.

\section{Daftar Pustaka}

AF (inisial). Gay: Islam dan Orientasi Seksual. Perekaman audio, August 17, 2018.

Alves, Maria Juscinaide Henrique, Jeanderson Soares Parente, and Grayce Alencar Albuquerque.

"Homosexual Orientation in Childhood and Adolescence: Experiences of Concealment and

Prejudice." Reprodução \& Climatério 31, no. 2 (May 2016): 68-75.

https://doi.org/10.1016/j.recli.2016.03.002.

ANI (inisial). Gay: Islam dan Orientasi Seksual. Perekaman audio, August 20, 2018.

AR (inisial). Gay: Islam dan Orientasi Seksual. Perekaman audio, August 5, 2018.

Bennett, Linda Rae. "Zina and the Enigma of Sex Education for Indonesian Muslim Youth." Sex

Education 7, no. 4 (November 1, 2007): 371-86.

https://doi.org/10.1080/14681810701635970.

Bobrow, David, and J. Michael Bailey. "Is Male Homosexuality Maintained via Kin Selection?"

Evolution and Human Behavior 22, no. 5 (September 1, 2001): 361-68.

https://doi.org/10.1016/S1090-5138(01)00074-5.

Boellstorff, Tom. "Between Religion and Desire: Being Muslim and Gay in Indonesia." American Anthropologist 107, no. 4 (December 1, 2005): 575-85.

https://doi.org/10.1525/aa.2005.107.4.575.

. "Gay Dan Lesbian Indonesia Serta Gagasan Nasionalisme." Jurnal Antropologi Indonesia 30, no. 1 (2006): 1-6. https://doi.org/10.7454/ai.v30i1.3550.

. The Gay Archipelago: Sexuality and Nation in Indonesia. Princeton: Princeton University Press, 2005.

The gay archipelago: sexuality and nation in Indonesia. Princeton: Princeton University

Press, 2005.

. "The Perfect Path: Gay Men, Marriage, Indonesia." GLQ: A Journal of Lesbian and Gay

Studies 5, no. 4 (1999): 475-509. https://doi.org/10.1215/10642684-5-4-475.

Capriati, Wigke, and Yogi Setya Permana. "Gerak Progresif Gerakan Gay Kontemporer Di

Yogyakarta.” Jurnal Ilmu Sosial Dan Ilmu Politik 12, no. 1 (2008): 59-77.

https://doi.org/10.22146/jsp.10986.

Cass, Vivienne C. "Homosexuality Identity Formation:” Journal of Homosexuality 4, no. 3 (April

24, 1979): 219-35. https://doi.org/10.1300/J082v04n03_01.

Ciani, Andrea Camperio, Francesca Iemmola, and Stan R. Blecher. "Genetic Factors Increase

Fecundity in Female Maternal Relatives of Bisexual Men as in Homosexuals." The Journal of Sexual Medicine 6, no. 2 (February 2009): 449-55. https://doi.org/10.1111/j.1743-

6109.2008.00944.x.

Cresweel, John W. Research design: pendekatan metode kualitatif, kuantitatif, dan campuran.

Translated by Achmad Fawaid and Rianayati Kusmini Pancasari. Yogyakarta: Pustaka

Pelajar, 2017. 
Dharma Setyawa, ed. Proceding: Tinjauan Terhadap Lebian Gay Biseksual dan Transgender (LGBT) Dari Perspektif Hukum Pendidikan Dan Psikologi. Lampung: Program Pascasarjana STAIN Jurai Siwo Metro Lampung, 2016.

Gozan, Misri. "Perilaku Homoseksual: Mencari Akar Pada Faktor Genetik." Nizham Journal of Islamic Studies 4, no. 1 (October 12, 2017): 75-87.

GPY (inisial). Gay: Islam dan Orientasi Seksual. Perekaman audio, August 16, 2018.

Hamer, D., S Hu, V. Magnuson, N Hu, and A. Pattatucci. "A Linkage between DNA Markers on the X Chromosome and Male Sexual Orientation.” Science 261, no. 5119 (July 16, 1993): 321-27. https://doi.org/10.1126/science.8332896.

hidayati, Titin Nur. "Kehidupan Keagamaan Kaum Santri Waria di Pesantren Waria Al-Fatah Senin-Kamis Notoyudan Yogyakarta.” Jurnal Falasifa 1 (2010): 16.

HR (inisial). Gay: Islam dan Orientasi Seksual. Perekaman audio, August 12, 2018.

Iemmola, Francesca, and Andrea Camperio Ciani. "New Evidence of Genetic Factors Influencing Sexual Orientation in Men: Female Fecundity Increase in the Maternal Line." Archives of Sexual Behavior 38, no. 3 (June 1, 2009): 393-99. https://doi.org/10.1007/s 10508-0089381-6.

IKW (inisial). Gay: Islam dan Orientasi Seksual. Perekaman audio, August 5, 2018.

Jonathan, A. Smith. Qualitative Psychology: Practical Guide to Research Methods. Translated by Muhammad Khozim. II. Bandung: Nusa Media, 2013.

Knoll, Megan, Claire J. Starrs, and J. Christopher Perry. "Rationalization (Defense Mechanism)." In Encyclopedia of Personality and Individual Differences, edited by Virgil Zeigler-Hill and Todd K. Shackelford, 1-5. Cham: Springer International Publishing, 2016. https://doi.org/10.1007/978-3-319-28099-8_1419-1.

Koeswinarno, Koeswinarno, and Mutolehudin Mustolehudin. "Islam, Gay, and Marginalization: A Study on the Religious Behaviours of Gays in Yogyakarta." Indonesian Journal of Islam and Muslim Societies 7, no. 1 (June 1, 2017): 125-52. https://doi.org/10.18326/ijims.v7i1.125-152.

"Lesbian-Gay-Sodomi-Dan-Pencabulan.Pdf." Accessed October 2, 2018. https://mui.or.id/wpcontent/uploads/2017/02/Lesbian-Gay-Sodomi-dan-Pencabulan.pdf.

Mason, Jennifer. Qualitative Researching. 2nd ed. London; Thousand Oaks, Calif: Sage Publications, 2002.

Mastuti, Ratri Endah, Rachmad Djati Winarno, and Lita Widyo Hastuti. "Pembentukan Identitas Orientasi Seksual Pada Remaja Gay.” PREDIKSI 1, no. 2 (2012): 194.

McKinlay, Andrew, and Chris McVittie. Social Psychology and Discourse. Malden, MA ; Oxford: Wiley-Blackwell Pub, 2008.

Merriam, Sharan B. Qualitative Research in Practice: Examples for Discussion and Analysis. 1st ed. The Jossey-Bass Higher and Adult Education Series. San Francisco: Jossey-Bass, 2002.

Miles, Matthew B, and A. Michael Huberman. Analisis Penelitian Kualitatif. Translated by Tjerjep Rohendi Rohidi. Jakarta: UI-Press, 1992.

Mulya, Teguh Wijaya. "From Divine Instruction to Human Invention: The Constitution of Indonesian Christian Young People's Sexual Subjectivities through the Dominant Discourse of Sexual Morality." Asian Studies Review 42, no. 1 (January 2, 2018): 53-68. https://doi.org/10.1080/10357823.2017.1407918.

. "The Limit of Human Rights: Sexual Orientation, LGBTI Activism, and Indonesian Youth.” Hiroshima, Japan, 2014. http://repository.ubaya.ac.id/31504/.

Parlindungan, Raja, and Amalia Roza Brilianty. "Gambaran Religiusitas Pada Gay.” Jurnal RAP 5, no. 1 (February 24, 2017): 92-102.

Prabowo, Dwi Ananto, and Hesti Asriwandari. "Latar Belakang Sosiologis Dalam Terbentuknya Pola Perilaku Homoseksual Gay (Studi Kasus Di Kota Pekanbaru).” Jurnal Online Mahasiswa (JOM) Bidang Ilmu Sosial Dan Ilmu Politik 3, no. 2 (June 9, 2016): 1-13. 
Rahayu, Puji, Rina Satriani, and Hamada Adzani Mahaswara. "Aplikasi Gay: Perjuangan Dan

Ruang Negosiasi Identitas Bagi Kaum Gay Muda Di Yogyakarta.” Jurnal Studi Pemuda 3, no. 2 (June 23, 2016): 99-109.

Rice, George, Carol Anderson, Neil Risch, and George Ebers. "Male Homosexuality: Absence of Linkage to Microsatellite Markers at Xq28." Science 284, no. 5414 (April 23, 1999): 66567. https://doi.org/10.1126/science.284.5414.665.

Sanders, Douglas. "The Role Of Yogyakarta Principles." International Gay and Lesbian Human Rights Commission, August 4, 2008, 1-9.

"Sensus Penduduk 2010 - Penduduk Menurut Wilayah dan Agama yang Dianut | Indonesia." BPS. Accessed October 1, 2018. https://sp2010.bps.go.id/index.php/site/tabel?tid=321.

Susanki, and Dian Anggraini Oktavia. "Kehidupan Waria di Jorong Mandiangin, Kecamatan Kinali, Kabupaten Pasaman Barat.” Jurnal Ilmu Sosial Mamangan 2, no. 2 (January 12, 2017): 101-7. https://doi.org/10.22202/mamangan.1374.

SZ (inisial). Gay: Islam dan Orientasi Seksual. Perekaman audio, July 29, 2018.

Vaillant, George Eman. “Adaptive Mental Mechanisms.” American Psychologist 55, no. 1 (2000): 89-98. https://doi.org/10.1037//0003-066X 55.1.89.

_. "Ego Mechanisms of Defense and Personality Psychopathology." Journal of Abnormal Psychology Vol. 103, no. No. 1 (1994): 44-50. https://doi.org/0021-843X/94/S3.00.

Wade, Carole, and Carol Tavris. Psikologi: Edisi Kesembilan. Translated by Padang Mursalin and Dinastuti. 9th ed. jilid 2. Jakarta: Erlangga, 2007.

Zaviera, Ferdinand. Teori Kepribadian Sigmund Freud. III. Yogyakarta: PRISMASOPHIE, 2016. 